\title{
Meta-analysis of association of insertion/deletion polymorphism of angiotensin I-converting enzyme gene with diabetic nephropathy and retinopathy
}

\author{
T.Fujisawa ${ }^{1}$, H. Ikegami ${ }^{1}$, Y. Kawaguchi ${ }^{1}$, Y.Hamada ${ }^{1}$, H. Ueda ${ }^{1}$, M.Shintani ${ }^{1}$, M. Fukuda ${ }^{2}$, T. Ogihara ${ }^{1}$ \\ ${ }^{1}$ Department of Geriatric Medicine, Osaka University Medical School, Osaka, Japan \\ ${ }^{2}$ Department of Ophthalmology, Osaka Teishin Hospital, Osaka, Japan
}

\begin{abstract}
Summary An insertion/deletion (I/D) polymorphism in the angiotensin-converting enzyme (ACE) gene has repeatedly been shown to be associated with ischaemic heart disease, but the association of this genetic marker with diabetic microangiopathy is controversial. To assess the association of the genotypes with the development of diabetic nephropathy or retinopathy, we performed a meta-analysis of data from the literature, using Mantel-Haenszel method followed by the Breslow-Day test for assessing homogeneity among data. In a total of 4773 diabetic patients from 18 studies with $(n=2495)$ and without $(n=$ 2278) renal complications, the $D$ allele was significantly associated with diabetic nephropathy $(p<$ 0.0001 ) in a dominant model (summary odds ratio $1.32,95 \%$ confidence interval: 1.15 to 1.51 ). There
\end{abstract}

was no significant evidence against homogeneity of the odds ratios $\left(\chi^{2}=18.9,20 d f ; p=0.53\right)$. The association was significant both in non-insulin-dependent $(p<0.005)$ and in insulin-dependent diabetes mellitus $(p<0.05)$. Likewise, in a total of 2010 diabetic patients with $(n=1008)$ and without $(n=1002)$ retinopathy, there was no association of the I/D polymorphism with diabetic retinopathy. These data suggest that the ACE I/D polymorphism affects the risk for diabetic nephropathy, but not for diabetic retinopathy. [Diabetologia (1998) 41: 47--53]

Keywords Angiotensin I-converting enzyme gene, I/D polymorphism, meta-analysis, diabetic nephropathy, diabetic retinopathy, genetic susceptibility.
Several lines of evidence from family and twin studies have strongly suggested that genetic factors are involved in the development of diabetic microangiopathy [1--3]. Several candidate genes have been investigated to elucidate genetic factor(s) responsible for the vascular complications, but little is known about the genetic basis of these complications $[4,5]$. Elucidation of the genetic factors predisposing to chronic vascular complications in diabetes mellitus will permit identification of individuals genetically predisposed to the complications and, in turn, will allow us

Received: 30 April 1997 and in revised form: 31 July 1997

Corresponding author: H. Ikegami, M.D., Ph. D., Department of Geriatric Medicine, Osaka University Medical School, 22 Yamadaoka, Suita, Osaka 565, Japan

Abbreviations: ACE, Angiotensin-converting enzyme; I/D, insertion/deletion; CI, confidence interval; $d f$, degrees of freedom. an effective intervention tailored to the specific underlying abnormalities.

The renin-angiotensin system regulates the systemic circulation and local haemodynamics, and also regulates cell growth and matrix production via its action on angiotensin II production. Angiotensin I-converting enzyme (ACE; EC 3.4.15.1) is not only a key enzyme in the renin-angiotensin system but also regulates kinin metabolism [6]. The plasma ACE level is under genetic control and is strongly associated with an insertion/deletion (I/D) polymorphism of the ACE gene, defined by the presence or absence of the 287 base-pair Alu-repetitive sequence in intron 16 [7]. Accordingly, the I/D polymorphism has been investigated as a strong candidate marker for genetic predisposition to diabetic vascular complications. Association studies of the ACE genotype with diabetic complications, however, have yielded conflicting results. 
In the present study we investigated whether or not the ACE genotype is associated with diabetic microangiopathy by performing a meta-analysis of the data from the literature.

\section{Subjects and methods}

Identification of studies. Medical reports based on clinical observations published in English after 1992, when the first report of the association of this genetic polymorphism with disease was published [8], were considered in this meta-analysis. In addition to identify studies, a search was performed on MEDLINE using the following keywords: (angiotensin converting enzyme or ACE) and (polymorphism or genotype or DD) and (diabetes mellitus or (insulin-dependent) IDDM or (non-insulin-dependent) NIDDM). In addition, complimentary searches in the references list of selected articles were performed. In each analysis, only studies with information on the genotype distribution according to the complications were included [9]. When diabetic complications according to the genotypes were reported for more than one subpopulation (for example, NIDDM and IDDM) in one study, each subpopulation was considered separately. In assessing risk for diabetic nephropathy, genotype data were divided into two separate groups, nephropathy group and control group. The nephropathy group consisted of patients with end-stage renal disease, macroalbuminuria, microalbuminuria (when urine albumin was measured quantitatively), and patients with proteinuria (when urine protein was qualitatively measured). The control group consisted of diabetic individuals defined as the control in each study. When patients were divided into more than two groups according to renal status, the nephropathy group consisted of those with microalbuminuria or more severe renal status. In another study, "decline group" " and "stable group" " defined originally in the manuscript were taken as the nephropathy group and the control group, respectively. As for diabetic retinopathy, genotype data were divided into two groups, retinopathy group and control group. The retinopathy group consisted of those showing retinal change, while the control group was defined as those having no signs of retinopathy with some restrictions as defined in each paper.

Statistical methods. For calculation of summary odds ratio according to the genotype groups, we adopted a fixed model using Mantel-Haenszel method [10] followed by the BreslowDay test for assessing the heterogeneity of the strength of the association [11]. The $95 \%$ confidence interval (95\% CI) was also calculated.

\section{Results}

Meta-analysis of nephropathy. In total, 50 studies were retrieved by the search. With respect to the association of ACE genotype with nephropathy, a total of 18 studies with sufficient information have been published to date [12--29], and data on 21 subgroups containing diabetic subjects with $(n=2495)$ and without $(n=2278)$ nephropathy were available (Table 1$)$. In most studies, the genotype distribution in the control group was consistent with Hardy-Weinberg equilibrium, except for two study groups (Table 2)

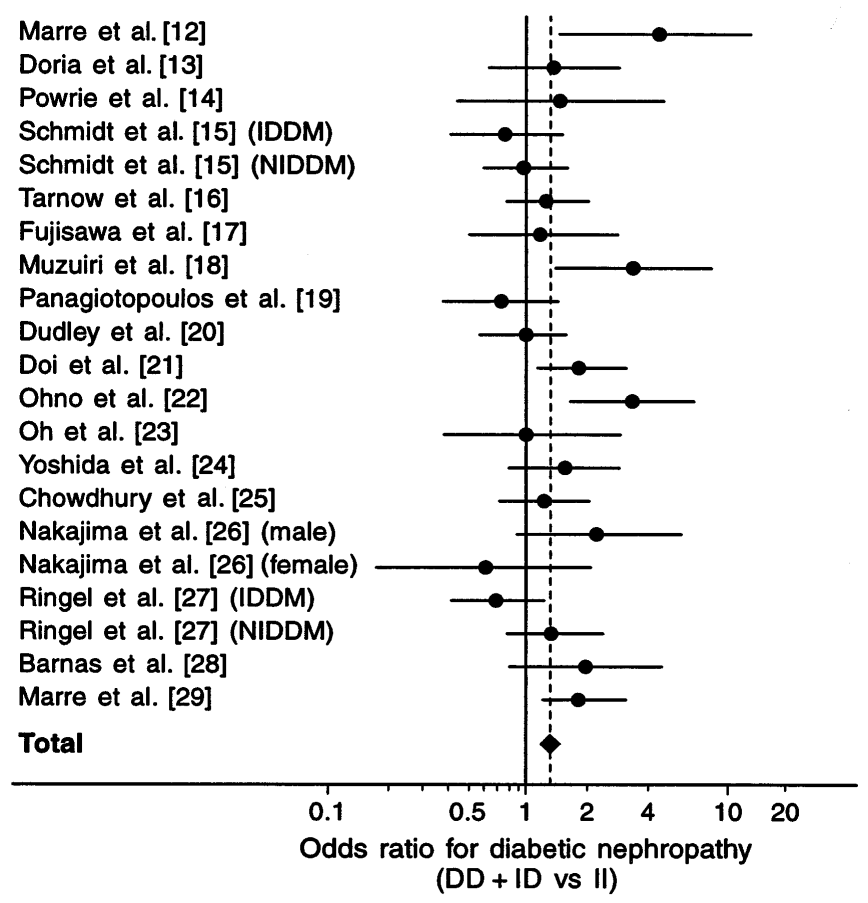

Fig. 1. Estimates of odds ratio for diabetic nephropathy according to insertion/deletion polymorphism of ACE gene. Values more than 1 imply an increased odds ratio for diabetic nephropathy associated with the DD + ID genotype (vs II genotype). $95 \%$ CIs expressed by bars (for each group) and $\diamond$ (for all studies combined). Broken vertical line represents summary odds ratio of the total pooled data. Reference number given in parenthesis

$[16,27]$. By the Mantel-Haenszel method, the D allele was significantly associated with diabetic nephropathy $(p<0.0001)$ in a dominant model (DD + ID vs II). The summary odds ratio for diabetic nephropathy was 1.32 (95\% confidence interval [CI]: 1.15 to 1.51) (Fig.1), indicating that the ratio of patients with/without nephropathy is 1.32 times higher in subjects with the D allele than in those without. In this model, there was no evidence for lack of homogeneity of the difference $\left(\chi^{2}=18.9\right.$ with $\left.20 d f, p=0.53\right)$, indicating that the results are compatible with a homogeneous association over the groups. By using the DerSimonian-Laird method, a random effect model, instead of the fixed effect model, the association of the $\mathrm{D}$ allele with nephropathy was also found to be significant (summary odds ratio: 1.25, 95\% CI: 1.03 to 1.52). Separate analysis of IDDM and NIDDM subgroups was also performed by independently comparing the association of ACE genotype with renal complications. The association of ACE genotype with nephropathy was significant both in patients with NIDDM $(p<0.005$, summary odds ratio: 1.36 , $95 \%$ CI: 1.22 to 1.64$)$ and in patients with IDDM $(p<0.05$, summary odds ratio: $1.28,95 \% \mathrm{CI}: 1.05$ to $1.57)$, where the test for heterogeneity in each group was not significant $\left(\chi^{2}=16.1\right.$ with $10 d f, p<0.09$ and 
Table 1. Characteristics of studies reporting ACE genotype distribution in diabetic patients with nephropathy and control subjects

\begin{tabular}{|c|c|c|}
\hline Study & Type of diabetes & Setting \\
\hline $\begin{array}{l}\text { Marre et al. } \\
{[12]}\end{array}$ & IDDM & $\begin{array}{l}\text { France, single centre, Cases: Incipient or established nephropathy (UAE } \geq 30 \mathrm{mg} / 24 \mathrm{~h} \text { ), } \\
\text { Control: age, sex duration retinopathy-matched normotensive normoalbuminuric } \\
\text { (UAE }<30 \mathrm{mg} / 24 \mathrm{~h} \text { ) patients from hospital }\end{array}$ \\
\hline $\begin{array}{l}\text { Doria et al. } \\
\text { [13] }\end{array}$ & IDDM & $\begin{array}{l}\text { USA, single centre, duration } 15 \text { to } 20 \text { years, Cases: micro- }(30<\text { AER }<250 \mu \mathrm{g} / \mathrm{min}) \text { or macro- } \\
\text { albuminuric }(\text { AER }>250 \mu \mathrm{g} / \mathrm{min}) \text { patients or patients with ESRD, Control: normoalbuminuric } \\
(\mathrm{AER}<30 \mu \mathrm{g} / \mathrm{min}) \text { patients }\end{array}$ \\
\hline
\end{tabular}

Powrie et al. IDDM

[14]

Schmidt et al. IDDM +

[15] NIDDM

Tarnow et al. IDDM

[16]

Fujisawa et al. NIDDM

[17]

Mizuiri et al. NIDDM

[18]

Panagiotopoulos NIDDM

et al. [19]

Dudley et al. NIDDM

[20]

Doi et al. NIDDM

[21]

Ohno et al. NIDDM

[22]

Oh et al. IDDM

[23]

Yoshida et al. NIDDM

[24]

Chowdhury et al. IDDM

[25]

Nakajima et al. NIDDM

[26]

Ringel et al. IDDM +

[27] NIDDM

Barnas et al. IDDM

[28]

Marre et al. IDDM

[29]
UK, outpatient clinics, duration 5 to 20 years, Cases: developed microalbuminuria (albumin/ creatinine ratio $>3 \mathrm{mg} / \mathrm{mmol}$ ) or overt renal failure over 10 years follow up, Control: remaining normoalbuminuric (albumin/creatinine ratio $<3$ ) during the follow up

German and Polish, 5 German outpatient clinics and 1 Polish clinic and 5 dialysis centres in Germany, duration $>10$ years, Cases: microalbuminuria (UAE $>30 \mathrm{mg} / 24 \mathrm{~h}$ or $>250 \mu \mathrm{g} / \mathrm{min}$ ) or more severe, Controls: normoalbuminuric patients

Denmark, single outpatient clinic, Cases: persistent albuminuria of $300 \mathrm{mg} / 24 \mathrm{~h}$ with retinopathy, Control: age, sex, duration-matched persistent normoalbuminuric patients recruited from the outpatient clinic

Japan, 2 hospitals, Cases: persistent proteinuria or ESRD, Controls: without proteinuria, duration $>10$ years

Japan, 1 hospital, duration > 10 years, Cases: micro- (AER: 20--200 $\mu \mathrm{g} / \mathrm{min}$ ) or macroalbuminuric $(>200 \mu \mathrm{g} / \mathrm{min})$ patients, Controls: normoalbuminuric $(<20 \mu \mathrm{g} / \mathrm{min})$ patients

Australia, 1 hospital, Cases: micro- (20--200 $\mu \mathrm{g} / \mathrm{min})$ or macroalbuminuric ( $>200 \mu \mathrm{g} / \mathrm{min})$ patients, Controls: normoalbuminuric $(<20 \mu \mathrm{g} / \mathrm{min})$ patients

UK, selected among 4860 patients, Cases: patients with urine in top tertile of the median UAE, Controls: age, sex, age-at-diagnosis, $\mathrm{HbA}_{1 \mathrm{c}}$ and triglyceride-matched patients

Japan, hospital outpatient clinic, duration $\geq 10$ years, Cases: UAI $>30 \mathrm{mg} / \mathrm{g}$ creatinine or ESRD, Controls: UAI $<30 \mathrm{mg} / \mathrm{g}$ creatinine

Japan, hospital outpatient clinic, duration $\geq 5$ years, Cases: micro- $(10<\mathrm{UAI}<200 \mathrm{mg} / \mathrm{g}$ creatinine) and macroalbuminuric (UAI $>200 \mathrm{mg} / \mathrm{g}$ creatinine) or ESRD, Controls: normoalbuminuric (UAI $<30 \mathrm{mg} / \mathrm{g}$ creatinine) patients

Korea, Duration $>5$ years, Cases: patients with microalbuminuria $(20<$ AER $<200 \mu \mathrm{g} / \mathrm{min})$, overt proteinuria (urinary protein $>500 \mathrm{mg} / 24 \mathrm{~h}$ ) or ESRD, Controls: normoalbuminuric $(\mathrm{AER}<20 \mu \mathrm{g} / \mathrm{min})$ patients

Japan, hospital outpatient clinic, duration $\geq 10$ years, Cases: declining renal function as defined in the paper, Controls: with stable renal function

UK, multi-centre, Caucasian, Cases: patients with persistent Albustix positive, duration $>5$ years, Controls: patients without proteinuria, and duration $\geq 15$ years

Japan, hospital outpatient clinic, duration $\geq 5$ years, Cases: patients with microalbuminuria (UAI > $30 \mathrm{mg} / \mathrm{g}$ creatinine) persistent proteinuria, Controls: normoalbuminuric (UAI $<30 \mathrm{mg} / \mathrm{g}$ creatinine) patients

Germany, Caucasian, 1 diabetes clinic and 4 dialysis centres, Cases: albumin excretion $>30 \mathrm{mg} /$ $24 \mathrm{~h}$ or $>20 \mu \mathrm{g} / \mathrm{min}$, or ESRD, Controls: not specified

Austria, outpatient clinic, Cases: microalbuminuria of 30--300 mg/day or overt albuminuria or ESRD, Controls: not specified

France and Belgium, 17 diabetic clinics, past or present proliferative retinopathy, Cases: patients with microalbuminuria (urinary albumin $30-300 \mathrm{mg} / 24 \mathrm{~h}, 20--200 \mu \mathrm{g} / \mathrm{min}$, or $20--200 \mu \mathrm{g} / \mathrm{l}$ ) or established and advanced nephropathy, Controls: urinary albumin $<30 \mathrm{mg} / 24 \mathrm{~h},<20 \mu \mathrm{g} / \mathrm{min}$ or $20 \mathrm{mg} / \mathrm{l}$

UAE, urinary albumin excretion; AER, albumin excretion ratio; ESRD, end-stage renal disease; UAI, urinary albumin index

$\chi^{2}=2.2$ with $9 d f, p>0.9$, respectively). When the nephropathy group was limited to patients with macroalbuminuria or more severe nephropathy, the association of the ACE genotype with nephropathy was also significant $(p<0.005$, summary odds ratio: 1.33 , 95 \% CI: 1.10 to 1.62$)$ [16, 17, 19, 21, 22, 24--26, 29]. As the ethnic heterogeneity of the ACE polymorphism is well known, ethnic groups were separately analysed. The association was significant both in
Asian populations $(p<0.00005$, summary odds ratio: $1.79,95 \%$ CI: 1.37 to 2.33 : 8 subgroups) $[17,18,21-$ $24,26]$, and in Caucasian populations ( $p<0.05$, summary odds ratio: $1.18,95 \%$ CI: 1.00 to 1.39 : 13 subgroups [12--16, 19, 20, 25, 27--29], respectively.

Meta-analysis of retinopathy. As for the association of ACE genotype with diabetic retinopathy, data on diabetic individuals with $(n=1008)$ and without $(n=$ 
Table 2. Reported distribution of genotypes of AGE gene in diabetic patients with nephropathy and control subjects

\begin{tabular}{|c|c|c|c|c|c|c|c|c|}
\hline \multirow[t]{3}{*}{ Study } & \multicolumn{6}{|c|}{ Genotype } & \multirow[t]{3}{*}{$(\mathrm{HW})^{\mathrm{a}}$} & \multirow{3}{*}{$\begin{array}{l}\text { Odds } \\
\text { ratio }^{\text {b }}\end{array}$} \\
\hline & \multicolumn{3}{|c|}{ Nephropathy } & \multicolumn{3}{|c|}{ Control Subjects } & & \\
\hline & $\mathrm{DD}$ & ID & II & $\mathrm{DD}$ & ID & II & & \\
\hline Marre et al. [12] & 23 & 35 & 4 & 19 & 28 & 15 & 0.46 & 4.63 \\
\hline Doria et al. [13] & 24 & 35 & 15 & 16 & 41 & 20 & 0.55 & 1.38 \\
\hline Powrie et al. [14] & 7 & 8 & 4 & 24 & 37 & 24 & 0.23 & 1.48 \\
\hline $\begin{array}{l}\text { Schmidt et al. [15] (IDDM) } \\
\text { (NIDDM) }\end{array}$ & $\begin{array}{r}52 \\
101\end{array}$ & $\begin{array}{r}38 \\
105\end{array}$ & $\begin{array}{l}62 \\
41\end{array}$ & $\begin{array}{l}55 \\
83\end{array}$ & $\begin{array}{l}55 \\
91\end{array}$ & $\begin{array}{l}23 \\
34\end{array}$ & $\begin{array}{l}0.16 \\
0.29\end{array}$ & $\begin{array}{l}0.78 \\
0.98\end{array}$ \\
\hline Tarnow et al. [16] & 63 & 95 & 40 & 67 & 77 & 46 & 0.013 & 1.26 \\
\hline Fujisawa et al. [17] & 7 & 23 & 24 & 6 & 12 & 17 & 0.15 & 1.18 \\
\hline Mizuiri et al. [18] & 19 & 51 & 11 & 9 & 11 & 11 & 0.11 & 3.45 \\
\hline Panagiotopoulos et al. [19] & 37 & 38 & 25 & 30 & 50 & 20 & 0.92 & 0.75 \\
\hline Dudley et al. [20] & 47 & 85 & 31 & 70 & 148 & 49 & 0.059 & 0.96 \\
\hline Doi et al. [21] & 29 & 85 & 50 & 12 & 56 & 56 & 0.71 & 1.88 \\
\hline Ohno et al. [22] & 15 & 38 & 26 & 5 & 15 & 33 & 0.12 & 3.36 \\
\hline Oh et al. [23] & 10 & 9 & 12 & 7 & 10 & 11 & 0.15 & 1.02 \\
\hline Yoshida et al. [24] & 19 & 28 & 25 & 7 & 46 & 43 & 0.26 & 1.53 \\
\hline Chowdhury et al. [25] & 78 & 124 & 40 & 55 & 79 & 32 & 0.70 & 1.21 \\
\hline $\begin{array}{c}\text { Nakajima et al. [26] } \\
\text { (male) } \\
\text { (female) }\end{array}$ & $\begin{array}{r}10 \\
4\end{array}$ & $\begin{array}{l}35 \\
15\end{array}$ & $\begin{array}{l}20 \\
17\end{array}$ & $\begin{array}{l}1 \\
3\end{array}$ & $\begin{array}{r}11 \\
8\end{array}$ & $\begin{array}{r}12 \\
6\end{array}$ & $\begin{array}{l}0.43 \\
0.91\end{array}$ & $\begin{array}{l}2.25 \\
0.61\end{array}$ \\
\hline $\begin{array}{r}\text { Ringel et al. [27] (IDDM) } \\
\text { (NIDDM) }\end{array}$ & $\begin{array}{l}35 \\
44\end{array}$ & $\begin{array}{l}68 \\
84\end{array}$ & $\begin{array}{l}31 \\
33\end{array}$ & $\begin{array}{l}57 \\
35\end{array}$ & $\begin{array}{r}130 \\
69\end{array}$ & $\begin{array}{l}39 \\
36\end{array}$ & $\begin{array}{l}0.018 \\
0.87\end{array}$ & $\begin{array}{l}0.69 \\
1.34\end{array}$ \\
\hline Barnas et al. [28] & 17 & 35 & 11 & 7 & 34 & 18 & 0.14 & 2.08 \\
\hline Marre et al. [29] & 119 & 168 & 50 & 48 & 69 & 40 & 0.14 & 1.96 \\
\hline
\end{tabular}

Data are number of patients

${ }^{\mathrm{a}}$ Probability value for Hardy-Weinberg equilibrium in control group; ${ }^{\mathrm{b}}$ Odds ratio for DD + ID vs II genotypes

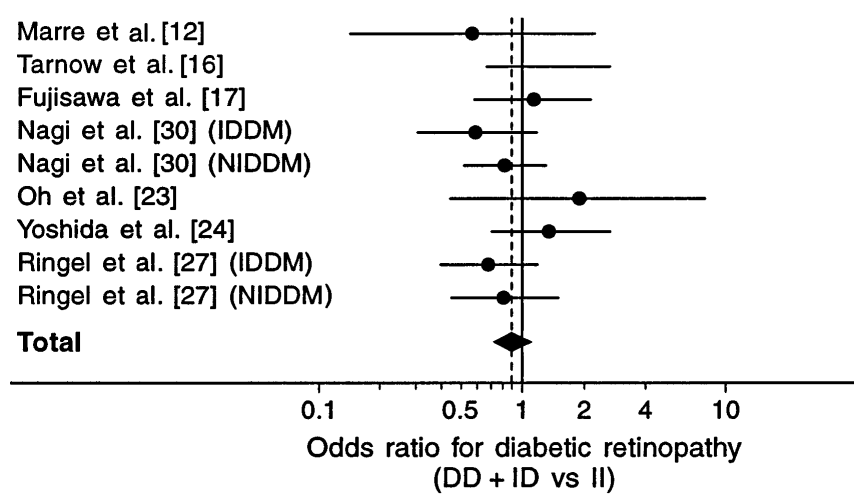

Fig. 2. Estimates of odds ratio for diabetic retinopathy according to insertion/deletion polymorphism of angiotensin-converting enzyme gene. $95 \%$ CIs expressed by bars (for each group) and $\diamond$ (for all studies combined). Broken vertical line represents summary odds ratio of the total pooled data. Reference number given in parenthesis

1002) retinopathy were available from seven studies $[12,16,17,23,24,27,30]$. The summary odds ratio of $\mathrm{D}$ allele in a dominant model (DD + ID vs II) for diabetic retinopathy was 0.91 (95\% CI: 0.73 to 1.13 ; eight subgroups) (Fig. 2), with no evidence of heterogeneity among the nine subgroups $\left(\chi^{2}=2.36,8 d f\right.$; $p>0.9)$.

\section{Discussion}

This study represents the first application of metaanalysis to assess the risk for diabetic microangiopathy in relation to the I/D polymorphism of the ACE gene. Based on data from more than 5000 diabetic individuals in total, it is concluded that this polymorphism is associated with diabetic nephropathy but not with diabetic retinopathy. In addition, the association among the diverse population groups exhibited a relatively similar strength despite the different genetic (including distribution of ACE genotypes) and environmental backgrounds. Therefore, the ACE I/ $\mathrm{D}$ polymorphism is suggested to affect the risk for diabetic nephropathy, but not for retinopathy, in a universal manner.

The calculated odds ratio of 1.32 presents us with two important pieces of information. First, assuming the $\lambda \mathrm{s}$ value, the degree of familial clustering of a disease, to be 2.17 for diabetic nephropathy based on the data on Caucasians $[3,31]$, it can be calculated from the estimation of odds ratio of 1.32 (95\% CI: 1.15 to 1.51) in D-allele carriers that the ACE locus contributes $28 \%(14--43 \%)$ to the familial clustering of nephropathy. Second, since D-allele carriers comprise $50-85 \%$ of each ethnic population and the $\mathrm{D}$ allele is universally associated with renal complica- 
tions, if the ratio of patients with/without nephropathy in D-allele carriers, were reduced from 1.32 times that in non-carriers to the non-carriers' own baseline, one would expect a 14--21\% reduction of renal insufficiency due to diabetic nephropathy throughout the world. The use of ACE inhibitors appears to be a theoretical intervention tailored to the underlying specific abnormalities, because it is possible that the $D$ allele exerts its effect via elevated ACE level. Indeed, in the management of individuals with proteinuria including diabetic subjects, the DD genotype was reported to be associated with administration of an ACE inhibitor having an antiproteinuric effect [32].

As shown in the current study, meta-analysis turned out to be a useful strategy for elucidating genetic factors in multifactorial disorders, such as diabetic complications. Due to the nature of multifactorial diseases, the impact of one genetic component on the development of the disease may be easily masked by other genetic and environmental factors. From this point of view, a meta-analysis is a powerful strategy, because: 1) it potentially investigates a large number of individuals; 2) it can estimate the impact of a genetic factor on the risk for the disease; and 3 ) it also can assess whether the association is common, or differs depending upon some specific clinical or genetic background feature [33]. Therefore, metaanalysis is potentially applicable for assessing the contribution of genetic factors not only to diabetic complications, but also to complex traits in general.

The development of diabetic microangiopathy is suggested to be, at least in part, genetically determined. Little is known, however, about the genetic factors responsible for the susceptibility. Furthermore, it is not clear whether genetic factors contributing to retinopathy and nephropathy are the same or different. In contrast to the significant association of the I/D polymorphism with diabetic nephropathy, our current meta-analysis as well as published reports did not support an association of the I/D polymorphism with diabetic retinopathy, suggesting that the ACE locus is unlikely to contribute to susceptibility to retinopathy. Alternatively, since the I/D polymorphism is associated with progression of other renal diseases $[34,35]$, the ACE locus may determine the susceptibility to renal damage in general, and, in coexistence with diabetes, it may act to increase the risk for diabetic nephropathy. The observed difference in the associations between retinopathy and nephropathy suggests that the genetic factors responsible for the two types of microangiopathy are different. Other possible interpretations derive from the difficulty in specifying an adequate endpoint (proliferative vs non-proliferative retinopathy).

An important unresolved issue concerning the effect of the D allele on disease susceptibility is the genetic mechanism; i.e. whether the effect is recessive, codominant, or dominant. The increased level of plasma ACE associated with the I/D polymorphism is suggested to be a codominant trait, with a low level in II genotype, intermediate in ID and highest in DD. As for the risk of the D allele for large vessel disease, taking into account a reported meta-analysis examining coronary heart disease [33] and three earlier studies investigating myocardial infarction in patients with NIDDM [17, 36, 37], the effect of the genotype may well be recessive (DD vs ID + II). In contrast, our present meta-analysis showed that the effect of the D allele on susceptibility to nephropathy is likely to be dominant. This is because the summary odds ratio calculated in a recessive model $(1.20,95 \% \mathrm{CI}$ : 1.06 to 1.37 ) was not higher than that in a dominant model (1.32), and the recessive model lessened homogeneity among groups $(p=0.31$ in a recessive vs $p=0.53$ in a dominant model, Breslow-Day test). Taken together, assuming that I/D polymorphism is involved in disease susceptibility through its effect on ACE level, it may be possible that the threshold for renal complications, if it exists, may be different from, and probably lower than, that for macroangiopathy.

Since the mechanisms of hyperglycaemia-induced tissue damage are likely to be common between NIDDM and IDDM, the genetic factors contributing to diabetic microangiopathy seem to be the same. However, there is little evidence supporting this hypothesis. Based on our separate analysis of NIDDM and IDDM, the association of the ACE genotype with diabetic nephropathy was found to be significant both in patients with NIDDM and in patients with IDDM. These data suggest a common genetic contribution, at least regarding the ACE I/D polymorphism, to diabetic complications in NIDDM and IDDM.

We are aware that these analyses have several limitations; namely limited number and size of available studies and the effect of publication bias, which may cause overestimation of the risk. Therefore, the results must be cautiously interpreted. Some of the odds ratios from the studies, in which originally no association was reported between diabetic nephropathy and ACE polymorphism, were more than 1.0 (Fig.1). In fact, in such studies, the bars for $95 \%$ CIs of the odds ratios cross the odds ratio $=1$ line. Many of them might not have enough power to detect the association. To confirm the hypothesis of the contribution of $\mathrm{D}$ allele to the genetic predisposition to diabetic nephropathy, a larger scale study is necessary; i. e. about 1200 cases, and a similar number of control diabetic individuals needs to be analysed to obtain a statistical power of $80 \%$ to detect a difference at $p=0.05$, given the effect on risk for nephropathy as 1.32 and II genotype frequency as 0.25 [34]. If the effect is smaller, as discussed above, a much larger size would be necessary. Thus, our meta-analysis also pro- 
vides information to help plan the sample size for future studies [38].

It is possible that heterogeneous groups were included in the nephropathy group. The additional analysis in which the nephropathy group was limited to patients with macroalbuminuria or more severe disease also showed that the association of ACE genotype with nephropathy was significant $(p<0.005)$. However, this approach does not distinguish whether the genotype increases the susceptibility to diabetic nephropathy or accelerates progression of existing nephropathy (or both). When one study [24], in which the patients without progression of nephropathy were treated as "stable" ", was excluded from the current meta-analysis, the summary odds ratio was 1.31 (95\% CI: 1.14 to 1.51 ), where the test for heterogeneity was not significant $(p=0.47)$.

In summary, our present meta-analysis demonstrated that the I/D polymorphism was associated with diabetic nephropathy, but not with retinopathy, across different population groups, suggesting that the ACE I/D polymorphism affects the universal risk for diabetic nephropathy, but not for retinopathy.

Acknowledgements. This work was supported in part by Grants-in-Aid for Scientific Research from the Ministry of Education, Science, Sports and Culture, a Grant for Diabetes Research from the Ministry of Health and Welfare, a grant from the SANDOZ Foundation for Gerontological Research and a grant from the Kato Memorial Trust for Nambyo Research.

\section{References}

1. Leslie RDG, Pyke AD (1982) Diabetic retinopathy in identical twins. Diabetes 31: 19--21

2. Seaquist ER, Goetz FC, Rich S, Barbosa J (1989) Familial clustering of diabetic kidney disease: evidence for genetic susceptibility to diabetic nephropathy. N Engl J Med 320: 1161--1165

3. Quinn M, Angelico MC, Warram JH, Krolewski AS (1996) Familial factors determine the development of diabetic nephropathy in patients with IDDM. Diabetologia 39: 940--945

4. Trevisan R, Viberti G (1995) Genetic factors in the development of diabetic nephropathy. J Lab Clin Med 126: 342-349

5. Chowdhury TA, Kumar S, Barnett AH, Bain SC (1995) Nephropathy in type 1 diabetes: the role of genetic factors. Diabet Med 12: 1059--1067

6. Erdos E, Skidgel RA (1987) The angiotensin I-converting enzyme. Lab Invest 56: 345--348

7. Rigat B, Hubert C, Alhenc-Gelas F, Cambien F, Covol P, Soubrier F (1990) An insertion/deletion polymorphism in the angiotensin I-converting enzyme gene accounting for half the variance of serum enzyme levels. J Clin Invest 86: 1343--1346

8. Cambien F, Poirier O, Lancerf L, et al. (1992) Deletion polymorphism in the gene for angiotensin-converting enzyme is a potent risk factor for myocardial infarction. Nature 359:641--644
9. Oxman AD, Cook DJ, Guyatt GH (1994) User's guide to the medical literature: VI. How to use an overview. JAMA 272: 1367--1371

10. Mantel N, Haenszel W (1959) Statistical aspects of the analysis of data from retrospective studies of disease. $\mathbf{J}$ Natl Cancer Inst 22: 719--748

11. Breslow NE, Day NE (1980) The analysis of case-control studies. In: Davis W (ed) Statistical methods in cancer research. Vol.1., International Agency for Research on Cancer. Lyon, pp 173--176

12. Marre M, Bernadet P, Gallois Y, et al. (1994) Relationships between angiotensin I converting enzyme gene polymorphism, plasma levels, and diabetic retinal and renal complications. Diabetes 43: 384--388

13. Doria A, Warram JH, Krolewski AS (1994) Genetic predisposition to diabetic nephropathy: evidence for a role of the angiotensin I-converting enzyme gene. Diabetes 43: 690-695

14. Powrie JK, Watts GF, Ingham JN, Taub NA, Talmud PJ, Shaw KM (1994) Role of glycaemic control in development of microalbuminuria in patients with insulin dependent diabetes. Brit Med J 309: 1608--1612

15. Schmidt S, Schöne N, Ritz E (1995) Association of ACE gene polymorphism and diabetic nephropathy? Kidney Int 47: 1176--1181

16. Tarnow L, Cambien F, Rossing P, et al. (1995) Lack of relationship between an insertion/deletion polymorphism in the angiotensin I-converting enzyme gene and diabetic nephropathy and proliferative retinopathy in IDDM patients. Diabetes 44: 489--494

17. Fujisawa T, Ikegami H, Shen G-Q, et al. (1995) Angiotensin I-converting enzyme gene polymorphism is associated with myocardial infarction, but not with retinopathy or nephropathy, in non-insulin-dependent diabetes mellitus. Diabetes Care 18: 983--985

18. Muzuiri S, Hemmi H, Inoue A, et al. (1995) Angiotensinconverting enzyme polymorphism and development of diabetic nephropathy in non-insulin-dependent diabetes mellitus. Nephron 70: 455--459

19. Panagiotopoulos S, Smith TJ, Aldred GP, Baker EJ, Jacklin CJ, Jerums G (1995) Angiotensin-converting enzyme (ACE) gene polymorphism in type II diabetic patients with increased albumin excretion rate. J Diabetes Complications 9: 272--276

20. Dudley CRK, Keavney B, Stratton IM, Turner RC, Ratcliffe PJ (1995) UK Prospective Diabetes Study. XV: Relationship of renin-angiotensin system gene polymorphisms with microalbuminuria in NIDDM. Kidney Int 48: 1907-1911

21. Doi Y, Yoshizumi H, Yoshinari M, et al. (1996) Association between a polymorphism in the angiotensin-converting enzyme gene and microvascular complications in Japanese patients with NIDDM. Diabetologia 39: 97--102

22. Ohno T, Kawazu S, Tomono S (1996) Association analysis of angiotensin-converting enzyme and angiotensinogen genes with diabetic nephropathy in Japanese non-insulindependent diabetes mellitus. Metabolism 45: 218--222

23. Oh TG, Shin CS, Park KS, et al. (1996) Relationship between angiotensin I converting enzyme gene polymorphism and renal complication in Korean IDDM patients. Korean J Intern Med 11: 133--137

24. Yoshida H, Kuriyama S, Atsumi Y, et al. (1996) Angiotensin I converting enzyme gene polymorphism in non-insulin dependent diabetes mellitus. Kidney Int 50: 657--664

25. Chowdhury TA, Dronsfield MJ, Kumar S, et al. (1996) Examination of two genetic polymorphisms within the renin- 
angiotensin system: no evidence for an association with nephropathy in IDDM. Diabetologia 39: 1108--1114

26. Nakajima S, Baba T, Yajima Y (1996) Is ACE gene polymorphism a useful marker for diabetic albuminuria in Japanese NIDDM patients? Diabetes Care 19: 1420--1422

27. Ringel J, Beige J, Kunz R, Distler A, Sharma AM (1997) Genetic variants of the renin-angiotensin system, diabetic nephropathy and hypertension. Diabetologia 40: 193--199

28. Barnas U, Schmidt A, Illievich A, et al. (1997) Evaluation of risk factors for the development of nephropathy in patients with IDDM: insertion/deletion angiotensin converting enzyme gene polymorphism, hypertension and metabolic control. Diabetologia 40: 327--331

29. Marre M, Jeunemaitre X, Gallois Y, et al. (1997) Contribution of genetic polymorphism in the renin-angiotensin system to the development of renal complications in insulindependent-diabetes: Génétique de la Néphropathie Diabétique (GENEDIAB) Study Group. J Clin Invest 99: 1585-1595

30. Nagi DK, Mansfield MW, Stickland MH, Grant PJ (1995) Angiotensin converting enzyme (ACE) insertion/deletion (I/D) polymorphism, and diabetic retinopathy in subjects with IDDM and NIDDM. Diabet Med 12: 997--1001

31. Krolewski AS, Warram JH, Rand LI, Kahn CR (1987) Epidemiologic approach to the etiology of type I diabetes mellitus and its complications. N Engl J Med 317: 1390-1398

32. Kitamura H, Moriyama T, Izumi M, et al. (1996) Angiotensin I-converting enzyme insertion/deletion polymorphism: potential significance in nephrology. Kidney Int 49: S101--S103

33. Samani NJ, Thompson JR, O'Toole L, Channer K, Woods KL (1996) A meta-analysis of the association of the deletion allele of the angiotensin-converting enzyme gene with myocardial infarction. Circulation 94: 708--712

34. Harden PN, Geddes C, Rowe PA, et al. (1995) Polymorphism in angiotensin-converting enzyme gene and progression of IgA nephropathy. Lancet 345: 1540--1542

35. McLaughlin KJ, Harden PN, Ueda S, Boulton-Jones M, Connell JMC, Jardine AG (1996) The role of genetic polymorphisms of angiotensin-converting enzyme in the progression of renal diseases. Hypertension 28: 912--915

36. Ruiz J, Blanché H, Cohen N, et al. (1994) Insertion/deletion polymorphism of the angiotensin-converting enzyme gene is strongly associated with coronary heart disease in non-insulin-dependent diabetes mellitus. Proc Natl Acad Sci USA 91: 3662--3665

37. Keavney BD, Dudley CRK, Stratton IM, et al. (1995) UK Prospective Diabetes Study (UKPDS) 14: association of angiotensin-converting enzyme insertion/deletion polymorphism with myocardial infarction in NIDDM. Diabetologia 38: 948--952

38. Kirkwood BR (1988) Calculation of required sample size. In: Kirkwood BR (ed) Essentials of medical statistics. Blackwell Scientific Publications, Oxford, pp 191--201 